\title{
Termini magyar-magyar szótár mint a határon túli magyar nyelvváltozatok lexikai adatbázisa ${ }^{1}$
}

\author{
M. Pintér Tibor \\ Károli Gáspár Református Egyetem, Bölcsészettudományi Kar
}

\begin{abstract}
A Termini magyar-magyar szótár a magyar nyelv határon túli változatainak kölcsönszavait szótárazza, szemantikai és lexikográfiai nézőpontból. A kizárólag online felületen létező szótár a magyar nyelv szinkrón állapotát tükrözi. Az ismertetés részleteiben mutatja be a szócikkszerkezetet, kitér a szerkesztés sajátosságaira, valamint emlitést tesz a szótár gyakorlati és szimbolikus felhasználási lehetöségeiröl.
\end{abstract}

Kulcsszavak: Termini Magyar Nyelvi Kutatóhálózat, magyar-magyar szótár, egynyelvü szótár, adatbázis, lexikográfia

A szótárhasználati szokásokat alapvetően az a tényező befolyásolja, hogy papíralapú vagy elektronikus szótárt használunk - a használati különbségek mögött elsősorban a használhatóság mögötti technológiai különbségek állnak. Ez a technológiai különbség befolyással van az olvasástechnikára, azon keresztül pedig az olvasás mennyiségére is. Az olvasás (bár elsősorban a papírkönyvek olvasásának) kognitív és kulturális fejlődésben betöltött haszna vitathatatlan (lásd pl. G. Gödény, 2016). Az is tény, hogy a generációk váltásával módosulnak az olvasási szokások, amelynek egyik alapját a kutatók a generációk infokommunikációs eszközökhöz füzött pozitív - viszonyában látják. A mai fiatalok (Z-generációtól későbbiek, sőt tulajdonképpen már az Y-generáció is; a generációk sajátosságairól bővebben lásd: M. Pintér, 2016, 14-15. o.) technokrata beágyazottságát kutatások is bizonyítják (például Guld és Maksa, 2013; Pál, 2013; Pintér és Székely, 2006; a digitális technika és kultúra kapcsolatával kapcsolatban Varga, 2012). A fiatalok olvasnak, csak mást, máshol, másképpen, mint azt tették a korábbi generációk. Magyarországi

\footnotetext{
${ }^{1}$ Az ismertetés alapjául szolgáló kutatást a Magyar Tudományos Akadémia támogatta a Határon Túli Magyar Tudományosságért Ösztöndíjprogram keretében, a Fórum Kisebbségkutató Intézet keretében mủködő Gramma Nyelvi Iroda munkaterve alapján.
}

oktatáskutatások egyik tanulsága, hogy az olvasás módja változik, az internet és számítógépek elterjedése elsősorban a rövidebb szövegek elterjedését és többféle forrás együttes olvasását eredményezte. A mai fiatalok olvasási szokását leginkább az internet és az információszerzés mozgatja (vö. Gombos, $\mathrm{He}$ vérné Kanyó és Kiss, 2015).

Az olvasás egy sajátos formája a szótárak lapozgatása, olvasása. Szótárat olvasni nem azonos értékű a szépirodalmi szövegek olvasásával - lévén, nem összefüggő szövegről van szó. Az vitathatatlan, hogy új vagy régi könyvet lapozgatni már csak a papír „szaga” miatt is érdekes, mint ahogy az is vitathatatlan, hogy másként olvasunk folyó szöveget és másként szótárakat (az olvasási technikákról bővebben lásd Gósy, 1999: 235-265).

A számítógép-használatnak is megvannak a maga pozitívumai (ha beszélhetünk könyvek „szagáról”, akkor miért ne beszélhetnénk billentyűzet „tapintásáról” - aki használt még Commodore 64 számítógépet és az ahhoz gyártott billentyűzetet, érti, mit is szeretnék ezzel a mondattal szemléltetni), így a könyv versus infokommunikációs eszköz használatában több tényező is dönthet. A papíralapú és számítógépen (telefonon, tableten, PDA-n vagy más eszközön) folytatott szótárhasználat mellett az utóbbi időkben elterjedni látszik egy új eszköz, a Google-fordító (translate. google.com) használata, amely egyszerűsége 
és gyorsasága miatt már magát a szótárhasználatot is „veszélyezteti” (a szótárhasználati szokásokról bővebben Márkus és Szöllösy, 2006).

Az internet (és az osztott adatbázisok, valamint a különféle jelölőnyelvek) adta lehetőséget használják ki azok a (szótár)kiadók, akik szótáraikat már vagy kizárólag csak az interneten teszik közzé. Magyarországon a legnagyobb szótárkiadók (a Grimm Kiadó és az Akadémiai Kiadó) leggyakrabban használatos szótáraikat már webes felületen is kínálják a használóknak (ami regisztrációs költséggel jár).

Írásomban egy kizárólag on-line felületen létező szótárat, a Termini magyar-magyar szótár és adatbázist, más néven ht-szótárat (ht.nytud.hu/htonline) mutatom be. Az adatbázis-alapú szótárak nagy előnye, hogy az egyszerűbb, gyorsabb és pontosabb keresés mellett olyan lehetőségeket is kínálnak, amelyeket a papírszótárak nem vagy csak nehézkesen - például a benne lévő összes adat egyszerre történő áttekintésére és statisztikák készítésére.

A 2017. augusztus 23-i állapot szerint a szótár 4689 szócikke 22964 jelentést tartalmazott.

A ht-szótár a magyar szótárak között több szempontból egyedülálló vállalkozás. A szótár létrehozója és működtetője a Termini Magyar Nyelvi Kutatóhálózat, amely hat határon túli magyar nyelvtudománnyal foglalkozó kutatócsoport hálózata. A kutatóhálózat tevékenységei között kiemelt szerepet kap az ún. „határtalantás”, amelyet következőképpen határoz meg: „hogy az újonnan készülő vagy átdolgozott magyarországi nyelvészeti kiadványokban jelentőségüknek megfelelő mértékben jelenjenek meg a magyar nyelv határon túli változatai, azaz a címük szerint a »magyar« nyelvet vagy annak valamely részrendszerét bemutató kiadványok (értelmező szótárak, idegen szavak szótárai, helyesírási szótárak és a helyesírás-ellenőrző számítógépes programok, szinonimaszótárak, névszótárak, csoportnyelvi szótárak, kétnyelvű szótárak, nyelvtanok, helyesírási, nyelvhasználati, stilisztikai kézikönyvek stb.) - címükkel összhangban - ne a magyarországi magyar nyelv- vel foglalkozzanak, hanem az egyetemes magyar nyelvvel, amely a magyarországi magyar nyelvváltozatokon kívül magába foglalja a határon túli magyar beszélőközösségek által beszélt nyelvváltozatokat is." (http://ht.nytud.hu/ htonline/present.php?action=hatartalanitas). A határtalanítás lényege, hogy a Magyarországon kiadott szótárak ne csak a magyarországi magyar nyelvváltozatok lexikális elemeit tartalmazzák, hanem a határon túli magyar nyelvváltozatokét is.

A nyelv és nyelvváltozat közti különbségek elsősorban racionálisak, nyelvpolitikai oldalról szabályosan körülhatárolhatóak, definiálhatóak. Azonban a nyelvet nem csak nyelvészek beszélik, nem steril környezetben (inkubátorban) létező kommunikációs eszköz. A racionális érvek mellett nem szabad megfeledkezni a beszélők személyes, érzelmi oldaláról sem. A nyelv nem csak rendszer, hanem a beszélők különféle, például szociális és emocionális beágyazottságának aktuális megjelenítője, hordozója. A puszta nyelvészeti racionalitás nem tud kimerítő választ adni például arra az egyszerű kérdésre, hogy a többközpontú nyelvek miért tekintődnek egy nyelvnek (miért nincs például „osztrák nyelv”), ugyanakkor több, különböző nyelv között miért van meg a kölcsönös érthetőség (csak a legnyilvánvalóbbak: cseh szlovák, spanyol portugál, román moldáv, orosz ukrán).

A magyar nyelv Magyarországon kívül még hét Kárpát-medencei országban őshonos nyelv (Szlovákiai, Románia, Ukrajna, Szlovénia, Horvátország, Ausztria, Szerbia). Ezekben az országokban a magyar nyelv kontaktusváltozatait beszélik, melyek egyik sajátossága, hogy grammatikájában, illetve szókészletében az ország államnyelvének elemeit tartalmazza. A Termini magyar-magyar szótár és adatbázis a Termini Magyar Nyelvi Kutatóhálózat által szerkesztett adatbázis-alapú szótár, amely a határon túli magyar nyelvváltozatok közvetett és közvetlen kölcsönszavait (az átadó nyelv változatlan formájú szava és az átvevő nyelv hangrendszeréhez, fonotaxisához illeszkedett formában meghonosodott szó), tükörszavait (az átadó nyelv mintájára keletkezett szavak), szókapcsolatait és jelentéseit szótárazza. 
Termini magyar-magyar szótár mint a határon túli magyar...

A szótárérettség alapvető feltétele, hogy az adott szó, szókapcsolat vagy jelentés az adott határon túli régió általános használatú eleme legyen, ne korlátozódjon valamely kisebb régióra vagy nyelvjárási területre. A szótár alapvetően a mai határon túli magyar nyelvhasználat elemeit tartalmazza, a két háború közti korszak szavaiból kevés van (a kevés számú elem inkább mutatóként, mintsem diakrón vizsgálatokra alkalmas komplex szókészletként van jelen). A szótárat egy időben nyolc országból szerkesztik, a szlovákiai magyar részt a Gramma Nyelvi Iroda gondozza.

A szótár előzménye a Pusztai Ferenc által föszerkesztett Magyar értelmezö kéziszótár 2003. évi kiadása előtti lexikográfiai munkálatok voltak: ez volt az első olyan Magyarországon szerkesztett, a magyar nyelvet reprezentáló szótár, amelybe már - még ha kis százalékban is - kerültek szavak, jelentések a határon túli nyelvváltozatokból (a szótár megjelenése előtt a Magyar helyesírás szabályaiban található szótárrész is tartalmazott néhány határon túli lexikális elemet, ebből három szlovákiai magyar tulajdonnevet). Ezek kiválasztását gondos lexikográfiai és lexikológiai munkálatok előz- ték meg, melynek végtermékeként létrejött egy sajátos, 2012 szócikkből álló, a szlovákiai, erdélyi és kárpátaljai magyar nyelvváltozat lexikális elemeit, jelentéseit és az azokat illusztráló példamondatokat tartalmazó, akkor még Word-fájlban létező gyüjtés, az ún. ht-lista.

Ez a gyüjtés a hét határon túli magyar régió (szlovákiai magyar, erdélyi magyar, kárpátaljai magyar, muravidéki magyar, drávaszögi magyar, őrvidéki magyar, vajdasági magyar) mellett sajátos elemként a magyarországi standard és az összes Kárpát-medencei régió nyelvhasználatát is bemutatja.

A ht-szótár számos tekintetben eltér a hagyományos értelemben vett szótárszerkesztési és szótárszerkezeti megoldásoktól (például a mikrostruktúra részletessége, a több régióból történő szinkrón szerkesztés, a webes megjelenés és szerkesztés), ugyanakkor a szótár tartalmilag megfelel a szótárszerkezeti kívánalmaknak (egynyelvű szótár, mely magyar nyelv határon túli magyar változatainak lexikáját mutatja be). A szótár mögötti adatbázis nyelvészeti, elsősorban lexikográfiai szempontból rendkívül gazdag szerkezetű - igyekszik minél részletesebb képet adni a

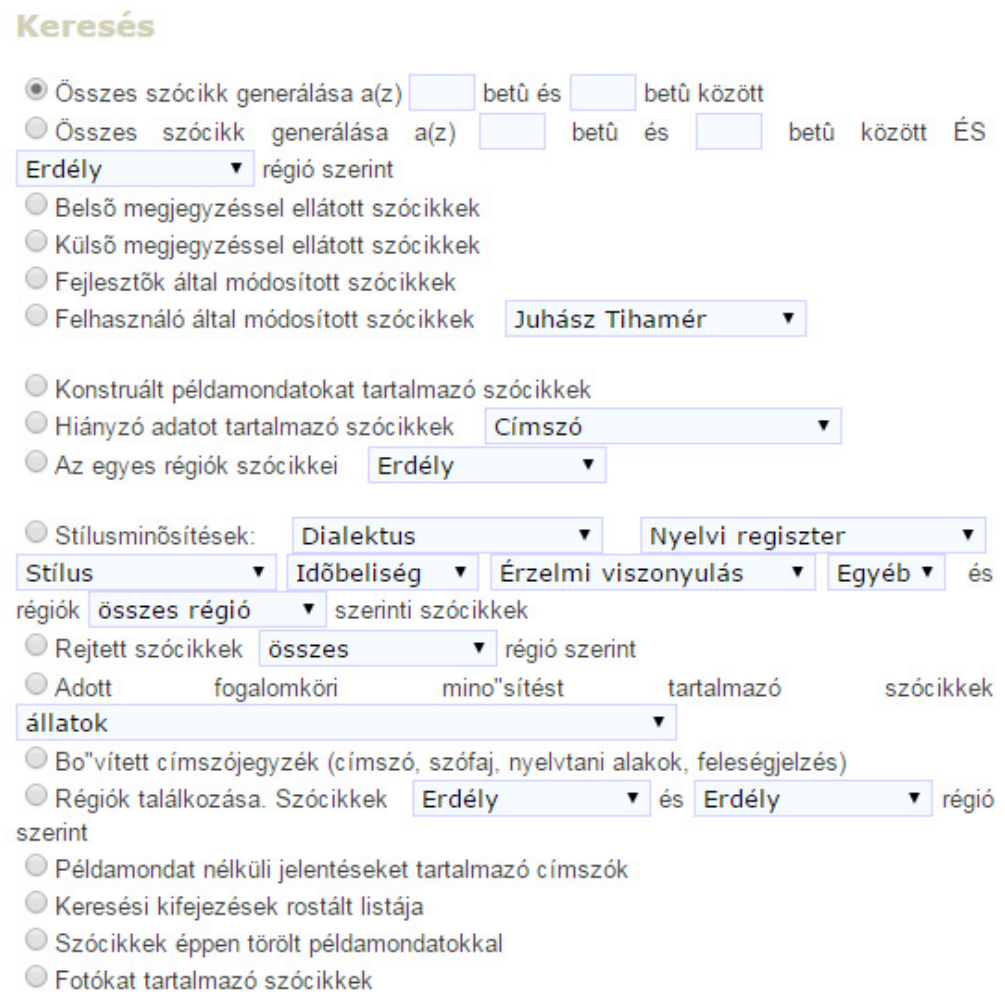

1. ábra: A ht-szótár keresőfelülete 


\begin{abstract}
rizsa $(\mathrm{fn}) \sim \mathrm{k}, \sim \mathrm{t}$, ja
1. (Gaszt) Fv (nép) (közh) (kissé biz), Va (nép) (közh) (biz), Mv (áit) (közh) (biz), Hu (nép) (közh) (biz) (ritk) rizs \& Fv Nehogy már azt higgye az öreglány, hogy "a marha szlovákok meg sem várják a gombás mártást, már eszik a snidlinges rizsát kenyérrel". (http://presstige.sk) • Fv A "diesotto" kifejezés elsôre úgy hangzik, mint valami olasz rizseshús. Pedig ez a "rizsa" forradalmasithatja a motorgyártást. A Mercedes által kifejlesztett új eróforrás, mint a neve is mutatja, lényegében a dízel- és a benzinmotor kombinációja, egyesitve azok elốnyeit. (www.ujszo.sk) • Fv Energiatartalom zöldséges rizs - Kukorica: $127 \mathrm{kcal}$ Sárgaborsó: 362 kcal Rizsa (hántolt)-345 kcal Napraforgóolaj: $898 \mathrm{kcal}$ Összesen: $1732 \mathrm{kcal}$ (www.eotvos.sk) \& Fv Alaptípusú termékeink rizsából készülnek igy lisztérzékenységben szenvedôk is fogyaszthatják. (http://celpo.sk) * • Fv Keminy ez a rizsa még, hadd fönyi... (www.tulok.sk) $\mathbf{v}$. Fv No mit csináljok a húsho, rizsát vagy krumpit? (Tallósi szótár)

2. Hu (ált) (közh) (biz) üres beszéd ^ Hu Nem olvastam vegig, mert sok a rizsa a honlapjukon, de allitolag 1992 ota mukodnek, amugy meg sok mindent leirtak, tehat nem valami 10 perc alatt osszedobott. (www.magyaroklondonban.com) $\triangleq$ Hu érdekes módon a jogsértések ma az országban mindennaposak, és sok példa van rá, hogy a rendốrség úgy csûri csavarja a törvényeket ahogy kénye kedve tartja, szóval akkor mirôl is beszélsz? // vagy csak nyomod az agyatlan rizsát? (http://forum.index.hu)

[szrb riža 1. 'rizs' 2. 'rizsszem', 3. 'rizsböl készült étel' < lat oriza 'rizs, rizskása'] $(\rightarrow$ rizsás)
\end{abstract}

2. ábra: A 'rizsa' szócikk (a szócikk grafikus elrendezésének köszönhetően könnyen áttekinthető szerkezet)

címszó mögötti lexikális és konceptuális tartalmakról. Az online megjelenés, illetve az adatbázisból történő betöltés előnye, hogy a használó a lekérdezőfelületen beállíthatja, hogy mindebből milyen információkat kíván a keresett szóról megjeleníteni.

A szócikkek mikrostruktúrája ${ }^{2}$ a lexikográfiai hagyományoknak megfelelően három, egymástól tipográfiailag is elkülönülő részből áll: szócikkfej, szócikktörzs, szócikkláb.

A szócikkfej elemei két kategóriába sorolhatók, azok az elemek, amelyeket a szótár minden szócikke tartalmaz, illetve azok az elemek, amelyek csak bizonyos típusú szócikkeknél szerepelnek (ott, ahol nyelvészetileg indokolt). A szócikkfej alapvető információi láthatóak a 'rizsa' szócikkben: a címszó szótári alakja³,

\footnotetext{
2 A ht-szótár többsége önálló szócikk, azaz megtalálható benne a szócikkfej, szócikktörzs, szócikkláb is. A kisebb számban előforduló utaló szócikk a címszón kívül csupán utalást tartalmaz arra az önálló szócikkre, amelyben a címszóra vonatkozó információk megtalálhatók (utaló szócikkek általában az egyes címszók írásváltozatai lehetnek, amelyek kiejtésben nem, csak írásmódjukban különböznek a szócikk fő helyén szereplő címszótól.

3 Érdekes kérdést vet fel a címszavak helyesírása. Mivel a bekerülő címszavak vagy azok része valamely államnyelv elemei, így azok az adott régióban sokszor idegenes írásmóddal íródnak. Idegen, idegenes elemek lévén olyan szavak is előfordulnak címszóként, amelyet az adott
}

szófaja, valamint alapvető nyelvtani alakjai (főneveknél a többes számú ragtalan alak (-k), a tárgyragos jeltelen alak (-t), az egyes szám harmadik személyü birtokos személyjeles alak (-a/-e, -ja/-je); mellékneveknél a középfokjeles alak (-bb), a módhatározó ragos alak (-n/an/-en; -ul/-ül, -lag/-leg); határozószóknál a középfokjeles alak (-bb), illetve igéknél a tárgyasság, valamint a kijelentő módú, múlt idejü, alanyi ragozású, egyes szám első személyü alak, a kijelentő módú, múlt idejü, alanyi ragozású, egyes szám harmadik személyű alak, illetve a felszólító módú, alanyi ragozású, egyes szám harmadik személyü alak.

Elsősorban a nyelvi kontaktus során változatlan alakban átvett szavaknál a szótár jelöli azok kiejtési alakjait, illetve - a másnyelvi grafémákból adódó - írásváltozatát vagy írás-

\footnotetext{
régióban nem vagy csak ritkán írnak le (azért, mert az adott régióban nem tartják magyar elemnek). Alapvető szerkesztési szabály, ha a címszó valamely régióban rendelkezik latin betűs írásváltozattal (elsősorban az írott szavak, föként a hivatali nyelvhasználat elemei), az az írásváltozatot használják címszóként is. Ha az adott szónak nincs valós írott alakja (elsősorban a beszélt nyelvi elemek), akkor azt a mindenkori magyar helyesírás szabályai szerint írják le. A kárpátaljai és vajdasági magyar nyelvváltozatok, azaz a nem latin betűs esetében a szerkesztők a kiejtést követik (transzliterálnak).
} 
Termini magyar-magyar szótár mint a határon túli magyar...

változatait. Az írásváltozat kiejtésben változatlan címszó, mely csupán írott alakjában, alakjaiban különbözik attól. Az írásváltozatot a címszó utáni kerek zárójelben jelölt alak közli. Az írásváltozatok - az alakváltozatoktól eltérően - a maguk betürendi helyén nem alkotnak önálló szócikket, csupán utalást tartalmaznak az önálló szócikk címszavára. A címszó kiejtési változatát csak akkor tünteti fel a szótár, ha az eltér az írott alaktól, illetve ha a magyar nyelv kiejtési szabályaiból egyértelműen nem következik (a kiejtésváltozatot szögletes zárójelben találhatóak). Az ejtésváltozat azoknál a címszavaknál fordul elő, ahol a magyar hangrendszeréből hiányzó hang található vagy a beszédhang írásváltozata eltér a magyarban használatostól (például a szerb vagy ukrán sajátos beszédhangjai, illetve a szláv nyelvek diakritikus karakterei). Mivel a kiejtés az írásképhez képest kevésbé szabályozott, előfordul, hogy egy-egy címszónak több kiejtésváltozata is van. Az ejtésváltozat nem kerül külön szócikkbe, az írásváltozatokhoz hasonlatosan utalószócikként szerepelnek (online szótárként innen egy kattintásra elérhető az érintett szócikk is).

A szócikkek komplexitását a szócikktörzs részletessége bizonyítja. Ez két, egymástól elkülönülő információcsoportot, a címszó értelmezéséhez szükséges információkat és a használatot bemutató, illetve jelentést pontosító példamondatokat tartalmazza. A címszó értelmezését a jelentések száma, a jelenleg 46 fogalomköri minősítés, régió/földrajzi nyelvváltozat megnevezése, illetve a stílusminősítések (utalhat dialektusbeli, regiszterbeli, stílusváltozati hovatartozásra, időbeliségre, érzelmi viszonyulásra, valamint relatív gyakoriságra) segítik. Egynyelvű, értelmező szótárként az ekvivalensi szerepű értelmezés alapvetően háromféle lehet: szinonimikus, kifejtő vagy körülíró.

A magyarországi szótárak között szinte egyedülállóként a szótár különbséget tesz a példamondatok eredetére vonatkozóan. A szótár példamondatai nemcsak a jelentések minél pontosabb bemutatásának eszközei, mivel a lehető legtöbb példamondaton keresztül pontosítható a jelentés és jelentésár- nyalat, valamint a példamondatok különböző típusain keresztül bemutatható a címszó stilisztikai, nyelvhasználati éréke. Az elektronikus szótárak nagy előnye, hogy a szótárszerkesztőknek nem kell figyelni a feldolgozott (szó)anyag mennyiségére. A ht-szótár példamondatainak részletessége, illetve a lehetőség arra, hogy ilyen gazdag tipológiája is megjeleníthető, bizonyítja az on-line szótárszerkesztésben rejlő lehetőségeket.

A magyar nyelv szótáraiban (illetve grammatikáiban) található példamondatok sajátossága az irodalmi szövegektől az élőnyelvi szövegek felé történő elmozdulás. A hétkötetes értelmező szótár példamondatai bővelkednek szépirodalmi példákban (akár Arany Jánoséban), míg a mai szótárak igyekeznek nem csak a szépirodalomból, hanem az élő nyelvhasználatból meríteni. A korpuszalapú szótárak ma már nem elérhetetlen álom: a modernitás egyik jellemzője épp a korpuszalapúság ${ }^{4}$ lett.

A ht-szótár példamondatainak rendszere (egyszersmind a bennük rejlő lehetőségek)

\footnotetext{
${ }^{4}$ A korpuszalapúság kérdése történeti aspektusból eleve problematikus, mivel korpusz alatt mást értünk ma és
} mást értettek régebben. Mai értelemben véve korpusznak az elektronikusan tárolt, nyelvészetileg feldolgozott és annotált szövegeket tekintjük, amely nem kizárólag szépirodalmi szövegekből áll. A számítógép és a számítógépes szövegfeldolgozás elterjedése előtt a papírkiadásban megjelent irodalmi szövegek minősültek korpusznak - így például a Samuel Johnson által szerkesztett, 1755ben megjelent Dictionary of the English Language korpuszalapúnak minősült, mivel Johnson ügyelt rá, hogy példamondatai az akkor híres írók és költők műveiből származzanak (azaz nyoma van a szótár címszavainak, jelentéseinek és példamondatainak). A 20. század közepén íródott nagyszótárak (mint például a Bárczi Géza - Országh László által főszerkesztett hétkötetes A magyar nyelv értelmező szótára, illetve a Štefan Peciar által főszerkesztett hatkötetes Slovník slovenského jazyka [A szlovák nyelv szótára]) példamondataiban alapvetően még a szépirodalmi szövegekre épít - tehették mindezt a kor szellemének, nyelvészeti és irodalmi felfogásának köszönhetően. Ugyanakkor ma már furcsának hat az a szótár (és grammatika), amely példáit fóként a szépirodalmi szövegekre építi - mint a készülőben lévő szlovák-magyar nagyszótár. Korpuszalapúság tekintetében érdemes megnézni az érintett mű készítésének időpontját és hátterét, éppn azért, mert más korszakok más felfogással voltak a korpuszok iránt. 
túlmutat az általam ismert egy- és többnyelvű szótárakban található példamondatok belső struktúráján. A példamondatok elsődleges felosztása azok hitelességén alapul: a szótárszerkesztők igyekeztek valós, elhangzott vagy leírt példamondatokat használni, illetve kerülték a mondatok szerkesztők általi mondatírást (a szótár példamondatainak százalékos bontása az alábbi arányokat mutatja: hiteles, írott nyelvi $\approx 65 \%$, hiteles, beszélt nyelvi $\approx 5 \%$ és 30\%). Ennek tekintetében a szótár példamondatai három nagy típusra oszlanak:

- hiteles, írott nyelvi példamondat,

- hiteles, beszélt nyelvi példamondat,

- nem hiteles példamondat.

A hiteles példamondat nem elicitált beszédhelyzetből származik, azaz a példamondat írásban (akár online fórumon, akár szépirodalmi múben) megjelent, vagy adatközlőtől adatolhatóan, dokumentáltan szóban elhangzott. A nem hiteles vagy konstruált példamondatot vagy a szótárkészítők vagy a szótárkészítők felkérésére az adatközlők alkották. Ugyanezen kategória alá tartoznak az olyan konstruált mondatok, amelyek olyan szövegből származnak, amelyeket alkotójuk kifejezetten a ht-szó használatának illusztrálására hozott létre, valamint azok az elsődleges forrással ugyan rendelkező mondatok (például kisebb régiókat felölelő tájszótárak mondatai), amelyeknél nem kizárható keletkezésük konstruált mivolta.

Érdekes a szótárszerkesztők által használt 'nem hiteles' terminus: a metanyelvi jelentése (nem + hiteles) eleve preszupponálja a negatív konnotációt (bár a terminus létrejötte egyértelmű, a 'hiteles' mintegy ellentéteként). Szerencsésebb lenne a 'konstruált' jelező, mivel egyrészt nem utal a 'hiteles/nem hiteles' fogalomkörre, illetve talán jobban lefedi a példamondat keletkezésének módját - konstruált, azaz az adott helyzetben létrehozott, az adott nyelvi helyzetnek megfelelően szerkesztett.

A szerkesztők arra is ügyeltek, hogy jelezzék, a példamondatokat megalkotó személy rendelkezik-e nyelvészeti végzettséggel (például nyelvművelő). A példamondatok jelöléseinek egyik további érdekessége, hogy a szerkesztők - a szó régióbeli hovatartozása mellett - feltüntetik a beszélő régióbeli hovatartozását is, valamint a hiteles példamondatok esetében a forrást is.

A szócikk végén található szócikkláb utalásai három információt jelenítenek meg (mindegyik külön sorba szedve): egy részük azonos régióbeli alakváltozatokra utal, másik részük más régióbeli analóg szavakra, harmadik részük pedig az ugyanahhoz a szócsaládhoz tartozó, a szótárban megtalálható egyéb szavakra, attól függetlenül, hogy melyik régióban fordulnak elő.

A szótár lexikológiai haszna elsősorban a határon túli magyar lexikon lexikográfiai alaposságú összeírásában mutatkozik meg. A "nyelvészeti haszon” mellett gyakorlati hasznosíthatósága is fontos: a szótár szerkesztői számára kiemelten fontos, hogy lehetővé tegyék más felhasználóknak, hogy megismerjék más magyar nyelvváltozatok sajátos szavait, jelentéseit (Lanstyák, Benö és Juhász, 2010, 44. o.). A szóanyag lexikológiai (időbeli, térbeli, stílusbeli) és lexikográfiai feldolgozása (a szócikkek szerkezeti felépítése, a szócikkek közti kapcsolatok kidolgozottsága) lehetővé teszi, hogy a szótárat többféle felfogásban lássuk: ilyen „használati rétegek" például a következő, szótárhoz kapcsolható koncepciók: mai magyar nyelv értelmező szótára, általános szótár, idegen szavak szótára, illetve adatbázis-alapúság.

A szótár által feldolgozott lexikai anyag elsősorban a szinkron nyelvhasználatot tükrözi. Éppen ezért szívesen szótáraznak új szavakat is, amennyiben azok valamelyik korosztály nyelvhasználatában elterjedtek (mivel a szótár csak adatbázisként, illetve abból készített internetes szótárként létezik, a „szótáréretlennek” bizonyuló elemek könnyen törölhetőek). A mai magyar szókészlet feldolgozása mellett megtalálhatóak (igaz kis számban) a két világháború közti időszak vagy a szocializmus tipikus szavai is. A Hu felségjelzésű, azaz Magyarországon (is) használatos szavak jelentéseinek szinkrón diakrón állapotának vizsgálata, értelmezése magyarázatot ad(hat) a peremnyelvjárásokra jellemző archaikusságra. Bár szinkrón állapotot dolgoz fel, de a szótárban található elavult, régies vagy kissé régies használatú $H u$ felségjelzésű szavak ma egyes régi- 
Termini magyar-magyar szótár mint a határon túli magyar...

ókban mindennapos szavaknak vagy jelentéseknek minősülnek (például a Magyrországon régies jelentésű almérnök 'üzemmérnök', altiszt 'tiszthelyettes', hajtási igazolvány 'gépjárművezetői engedély', instruktor 'házitanító' vagy kalendárium 'naptár' (ezeket a - Magyarországon régiesnek minősülő - szavakat nevezi Benő Attila ún. megőrzött régiségnek, lásd Benö, 2013. 22. o.).

Mivel a szótár szóanyaga semmilyen tekintetben (sem stílusbeli, regiszterbeli, sem dialektusbeli viszonylatban) sem kötődik egy bizonyos nyelvváltozathoz, így az általános szótári jellege nyilvánvaló. A szóanyagot tekintve egy megkötés van: a szótárba bekerülő szónak, szókapcsolatnak vagy jelentésnek a határon túli magyar nyelvváltozatok egy nagyobb földrajzi területen elterjedt egységnek kell lennie, nem korlátozódhat kisebb földrajzi vagy bármely stilisztikai, esetleg regiszterbeli változathoz (ez persze nem jelenti azt, hogy egy olyan elem sem lenne a szótárban, amely csak valamely kisebb földrajzi régió vagy valamely regiszter, elsősorban valamely szakma sajátos szava lenne). Mivel a szótárba kerülő szavak, jelentések tipikusan valamelyik államnyelv sajátos egységei, amelyek azonban az adott régió magyar nyelvhasználatának mára szerves részei, ezért a szótár felfogható egyfajta idegen szavak szótárának is. A címszavak között olyanok is találhatóak, amelyek Magyarországon is használatosak, azonban - nem véletlenül - sajátos, a magyarországitól eltérő jelentésben. A ht-szótár vitalitását épp az adja, hogy adatbázisként müködik: a használók lekérdezéseken keresztül férnek hozzá a keresett szóhoz, jelentéshez. Az adatbázis-jellegnek több előnye is van (talán épp ezért a szerkesztők nem tervezik a szótár papír alapon történő megjelentetését), mely biztosítja a könnyebb szerkeszthetőséget és az egyszerűbb, igényre szabott megjeleníthetőséget. Ez lehet garanciája a szótár sikeres múködésének.

A Termini magyar-magyar szótár az egyetlen olyan komplex szótár, mely a magyar nyelv határon túli változatainak sajátos lexikális elemeit, illetve jelentéseit szótárazza. További egyedi jelleg a szerkesztés munkafolyamata, mivel a szótárat egy időben egyszerre 8 országból szerkesztik ${ }^{5}$ - tehetik mindezt azért is, mivel a szótár nem rendelkezik nyomtatott változattal. A lekérdezéseket (akár az egész szótár) és kimutatásokat a szótár felületén (ht.nytud.hu/htonline) regisztrált felhasználók valós időben (on-thefly) készíthetik el. A szótár anyagát nem csak a laikus nyelvhasználók, hanem a nyelvészek, a határon túli magyar nyelvváltozatokat kutatók is használják, hasznosítják.

Ha nem is lineáris olvasásra szánt és nem is papíralapú írásmű, de mindenképpen hasznos azok számára, akik jobban meg szeretnék ismerni a magyar nyelv valamely Kárpát-medencei állami változatának sajátos szókincsének jelentését, valamint használati szabályait.

\section{Felhasznált irodalom}

Benő Attila (2013): Tükörszerkezetek, jelentéskölcsönzések és megőrzött régiségek kisebbségi magyar nyelvváltozatokban. In: Szoták Szilvia és Vargha Fruzsina Sára (szerk.) Változó nyelv, nyelvváltozatok, területiség, Egyetemi Műhely Kiadó, Kolozsvár, 15-27.

G. Gődény Andrea (2016): Olvasáspedagógiai tanulmányok. Budapest: ELTE TÓK.

Gombos Péter, Hevérné Kanyó Andrea és Kiss Gábor (2015): A netgeneráció olvasási attitűdje - 14-18 évesek véleménye könyvekről, olvasásról, irodalomról - egy felmérés tanulságai. Ujj Pedagógiai Szemle, 65. 1-2. sz., 52-65.

URL: http://folyoiratok.ofi.hu/sites/default/files/ journals/upsz_2015_1-2_nyomdai.pdf

Gósy Mária (1999): Az olvasás. In: Gósy Mária Pszicholingvisztika. Corvina, Budapest, 235-265.

Guld Ádám és Maksa Gyula (2013): Fiatalok kommunikációjának és médiahasználatának vizsgálata. TÁMOP-4.2.3.-12/1/KONV2012-0016 Tudománykommunikáció a Z-generációnak címü kutatás jelentése. Pécsi Tudományegyetem, Pécs.

\footnotetext{
5 A szótár szerkesztésében az alábbi régiók és szerkesztők vesznek részt: Magyarország (Kitlei Ibolya), Szlovákia (Lanstyák István, M. Pintér Tibor), Románia (Benő Attila, Juhász Tihamér), Ukrajna (Márku Anita), Szerbia (Molnár Csikós László, Varga Tünde, Detki Gyöngyi), Szlovénia (Kolláth Anna), Horvátország (Lehocki Anna, Kovács Lea), Ausztria (Szoták Szilvia).
} 
Lanstyák István, Benő Attila és Juhász Tihamér (2010): A Termini magyar-magyar szótár és adatbázis. Regio, 21. 3. sz., 37-59.

M. Pintér Tibor (2016): Infokommunikáció használata a tanulásban. Elméleti megközelítés az oktatásinformatikai készségek fejlesztéséhez. Gyermeknevelés, 4. 2. sz., 11-23.

Márkus Katalin és Szöllősy Éva (2006): Angolul tanuló középiskolásaink szótárhasználati szokásairól. Lexikográfiai füzetek II., Akadémiai Kiadó, Budapest, 95-117.

Pál Eszter (2013, szerk.): A „Z” generációról Áttekintő tanulmány. TÁMOP-4.2.3.-12/1/ KONV-2012-0016 Tudománykommunikáció a Z-generációnak címü kutatás jelentése. Pécsi Tudományegyetem, Pécs.
Pintér Róbert és Székely Levente (2006): Bezzeg a mai fiatalok - a tizenéves korosztály médiafogyasztása a többségi társadalom tükrében. In: Dessewffy Tibor, Fábián Zoltán és Z. Karvalics László (szerk.) Internet.hu: a magyar társadalom digitális gyorsfényképe 3. Tárki Zrt., Budapest.

Varga Richárd 2012. A netgeneráció és az irodalomtanítás. In: Finta Gábor és Fűzfa Balázs (szerk.) Az irodalomtanitás innovációja. Savaria University Press, Szombathely, 166-177.

http://ht.nytud.hu/htonline/present.php?action $=$ hatartalanitas

\section{Lexical database of the Termini Hungarian-Hungarian dictionary of the language varieties spoken outside Hungary}

The Termini Hungarian-Hungarian dictionary involves lexicon used outside Hungary in the Carpathian Basin. The semantic and lexicographic material focuses on the Hungarian from synchronic view. The review presents the entry structure of the dictionary, taking into account the special process of editing and possible practical and symbolic use of the dictionary itself.

Keywords: Termini Research Network of the Hungarian Language, Hungarian-HUngarian dictionary, monolingual dictionary, database, lexicography

M. Pintér Tibor (2017): Termini magyar-magyar szótár mint a határon túli magyar nyelvváltozatok lexikai adatbázisa. Gyermeknevelés, 5. 3. sz., 123-130. 